OPEN ACCESS

\title{
Development of Science and Technology Park (STP) in Indonesia to Support Innovation-Based Regional Economy: Concept and Early Stage Development
}

\author{
Wisnu S. Soenarso, ${ }^{*}$ Dadan Nugraha, and Eryda Listyaningrum \\ Center for Research S\&T (Puspiptek), Ministry for Research and Technology, the Republic of Indonesia
}

\begin{abstract}
Science and Technology Park (STP) is perceived to be a vehicle in promoting innovation-based economic growth within the framework of regional and national innovation systems. STP is a tool to encourage regional innovation and competitiveness in increasing contribution of science and technology in economic development. STP can also be a leading sector in creating conducive environment for local community's technopreneurship. In relation to the vision outlined in the 2025 Indonesian Master Plan of Acceleration and Expansion of Indonesia's Economic (MP3EI), STP is stated to be an important element in creating innovation within the framework of Special Economic Zone among six Economic Corridors. Hence, the government of Indonesia continues to encourage the development of STPs in Indonesia by involving local governments, universities, business players and stakeholders surround the area. Ultimately, STP is a platform in developing National Innovation System (NIS) and Regional Innovation System (RIS).
\end{abstract}

Keyword : Science \& Technology Park, Innovation-based Economic, MP3El, Innovation System, Special Economic Zone

\section{INDONESIA'S NATIONAL INNOVATION SYSTEM}

Indonesia realizes that rapid development of science and technology has made it all the more important to acquire and make the best use of science and technology to strengthen its position in the globalstage. Thus, Indonesia draws up plans for the implementation, acquisition and utilization science and technology by adopting more advanced and strategic approaches. One of many efforts conducted by the government is by enacting Law of the Republic of

*Correspondence to : Wisnu S. Soenarso

Center for Research S\&T (Puspiptek), Ministry for Research and Technology, the Republic of Indonesia

E-mail : wisnu@ristek.go.id

World Technopolis Review

Copyright $\odot$ World Technopolis Association

CC This is an open-access article distributed under the terms of the Creative Commons Attribution Non-Commercial License(http://creativecommons.org/licenses/by-nc/3.0) which permits unrestricted noncommercial use, distribution, and reproduction in any medium, provided the original work is properly cited
Indonesia Number 18 of 2002 on National System of the Research, Development, and Application of Science and Technology. ${ }^{1}$ In return, this law is becoming a base for National Innovation System (NIS) in Indonesia.

NIS itself is defined as a system that induces the integration of institutional elements, resources, and networks of science and technology. The system explains that both central government and regional government along with the public should participate in encouraging, facilitating scientific activities and promoting the development and application of science and technology. When it comes to regional development, local government plays important roles in motivating, stimulating and facilitating conducive climates for the development of institutional elements, resources, and network of science and technology in their respective jurisdictions. ${ }^{2}$

\footnotetext{
${ }^{1}$ Indonesia, Law Of The Republic Of Indonesia On National System Of The Research, Development And Application OF Science And Technology, Law Number 18 Of 2002

2 Ibid. Article 20.
} 
Along with the National Innovation System, to boost its economic development, on 2011 the government of Indonesia enacts Master Plan of Acceleration and Expansion of Indonesia's Economic (MP3EI) 2011-2015 under Presidential Regulation No. 32 of 2011. MP3EI describes the 2025 's Indonesia vision. The stated vision is achieved by focusing on 3 main goals, namely:

a) To increase value added and to expand value chain for industrial production processes by increasing the efficiency of the distribution network and the capability of the industry to access and utilize natural resources and human resources

b) To encourage efficiency in production and to improve marketing aspects in order to integrate domestic markets.

c) To strengthen the national innovation system especially in relation to the aspects of production, process and marketing in order to achieve a sustainable competitiveness towards an innovation driven economy.

Strategy in implementating MP3EI will integrate 3 main elements:(1) Developing regional economic; (2) Strengthening national connectivity - both local and international; and (3) Strengthening human resource capacity and national science and technology to support the development of main programs in all economic corridors.

Referring to the stated vision and strategy in MP3EI, especially the third strategy, it can be seen that developing national science and technology is very crucial in strengthening national innovation system (NIS). When it comes to local and regional economic development, developing new growth regional center in each economic corridor is main efforts to support NIS.

Developing new growth regional center is essentially integrating sectoral and regional development approaches. The purpose of developing new growth centers is to optimize agglomeration advantages, to explore regional strengths and to reduce spatial imbalance of economic development throughout the country.

In the past, Indonesia has conducted policy in realizing national science and technology center called The Indonesian Research Centre for Science and Technology (Pusat Penelitian Ilmu Pengetahuan dan Teknologi/ Puspiptek). The development started in 1976 aimed at building a complex of research institutes and knowledge based enterprises. The Science Centre operates a well operated diversified set of 30 research laboratories and employing over 4000 Staff member. It's the potential resource in Indonesia to develop science and technology.

Nowadays, efforts in realizing the development of new growth centers across Indonesia will be directing in addressing common problems in science and technology development. The common problem will be explained as follows.

As for Indonesia, despite relatively good performance of its economy, contribution of science and technology sector in economic growth is still relatively low. According to the report of World Economic Forum (WEF) in 2012, Indonesia is part of group countries that are in the efficiency-driven stage, countries whose economies are based on the efficient production processes. In the report, it is also stated that according to the global competitiveness index (GCI), Indonesian position is moving up from rank 54 in 2009 to 44 in 2010, though later on Indonesia dropped into rank of 46 in 2011 and 50 in $2012<$ Table $1>$.

Table 1. Indonesia's Position in the Global Competitiveness Index (GCI) Compared To ASEAN Countries

\begin{tabular}{l|c|c}
\hline \multirow{2}{*}{ Country / Economy } & GCl 2012-2013 & GCl 2011-2012 \\
\cline { 2 - 3 } & Rank & Rank \\
\hline Singapore & 2 & 2 \\
\hline Malaysia & 25 & 21 \\
\hline Brunei Darussalam & 28 & 28 \\
\hline Thailand & 38 & 39 \\
\hline Indonesia & 50 & 46 \\
\hline Philippines & 65 & 75 \\
\hline Vietnam & 75 & 65 \\
\hline
\end{tabular}

Source: World Economic Forum, www.weforum.org / GCR (2012)

One of pillars in which is measured in global competitiveness index calculation is the technological readiness - that is for the case of Indonesia still needs to be improved. The technological readiness is the extent to which industries are able to absorb the technology to increase the productivity of their industry.

Moving to pillar of innovation, Indonesia ranked quite high and increased from the 47th position in 2008 to 39th position in 2009, and the 36th position in 2010 and 2011 and 
Table 2. Indonesian Innovation Pillar among ASEAN Country

\begin{tabular}{|c|c|c|c|c|}
\hline \multirow{2}{*}{ State } & \multicolumn{4}{|c|}{ Year } \\
\hline & 2009 & 2010 & 2011 & 2012 \\
\hline Singapore & 8 & 9 & 8 & 11 \\
\hline Malaysia & 24 & 24 & 24 & 23 \\
\hline Indonesia & 39 & 36 & 36 & 40 \\
\hline Thailand & 57 & 52 & 54 & 55 \\
\hline Brunei & 75 & 69 & 68 & 62 \\
\hline
\end{tabular}

Source: WEF Report, 2009-2012.

39 in 2012. Pillar innovation is an indicator that shows the ability of a nation to innovate technology in order to improve the living standards of the people.

Looking at some figures mentioned above, Indonesia is a country with great innovation ability, however its utility is still weak. Hence, its challenge is about how to bridge the high innovation capacity on one hand with the efforts of utilization on the other hand. Collaboration and synergy among researchers, engineers and academics as a technology provider with businesses sector as users of technology in developing competitive products, is becoming the key in improving the competitiveness of the national economy. To build the collaboration, interaction between the two sides providers/technology developers and users of technology should be strengthened.

Apart from the weak aspect in utilizing R\&D results, there are also some critical problems that need to be addressed soon by the government, namely:

- The role of manufacturing industries in Indonesia which reached only $27.9 \%$ of GDP in 2008 and is showing a decreasing trend

- Relatively low contribution of S\&T to the national economy (only $11 \%$ of export contributed by high tech products in 2007)

- R\&D Expenditure as percentage to GDP in 2008 is $0.08 \%$

- R\&D Investment from public compare to private $=70: 30$

- Indonesia has 2638 universities, but mostly are "teaching" university instead of "research" or "entrepreneur" university

- Relatively low of innovation collaboration

- Government's R \& D Institution and university are not being innovation source for industries
- Industrial innovation still limited, especially at food and beverages industry only

Not withstanding the problem mentioned above, Indonesia have potential resources to support NIS. There are abundant R\&D human resources from higher education sector, manufacturing industry sector, and government sector as below.

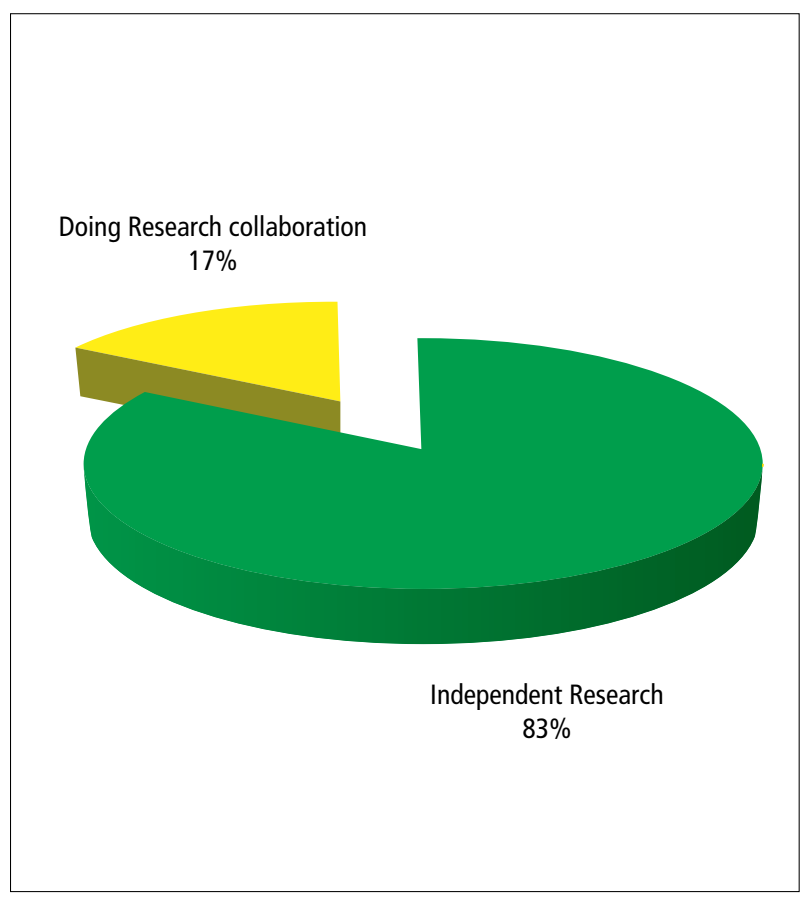

Fig. 1. Innovation Collaboration In Indonesia

Source: Innovation of Manufacture Industries' s Survey, 2009 PAPPIPTEK-LIPI 


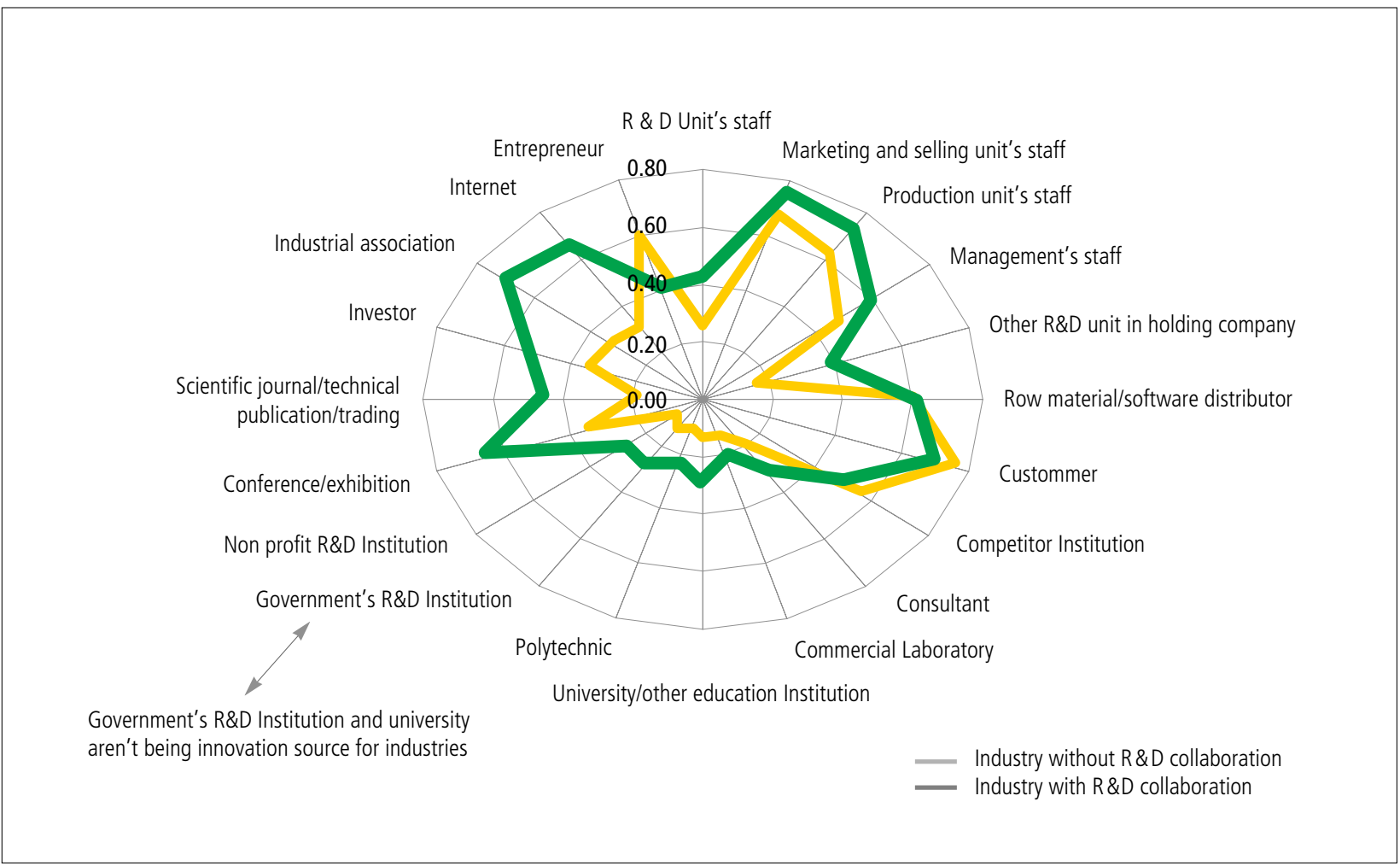

Fig. 2. Innovation Source

Source: Innovation of Manufacture Industries's Survey, 2009 PAPPIPTEK-LIPI

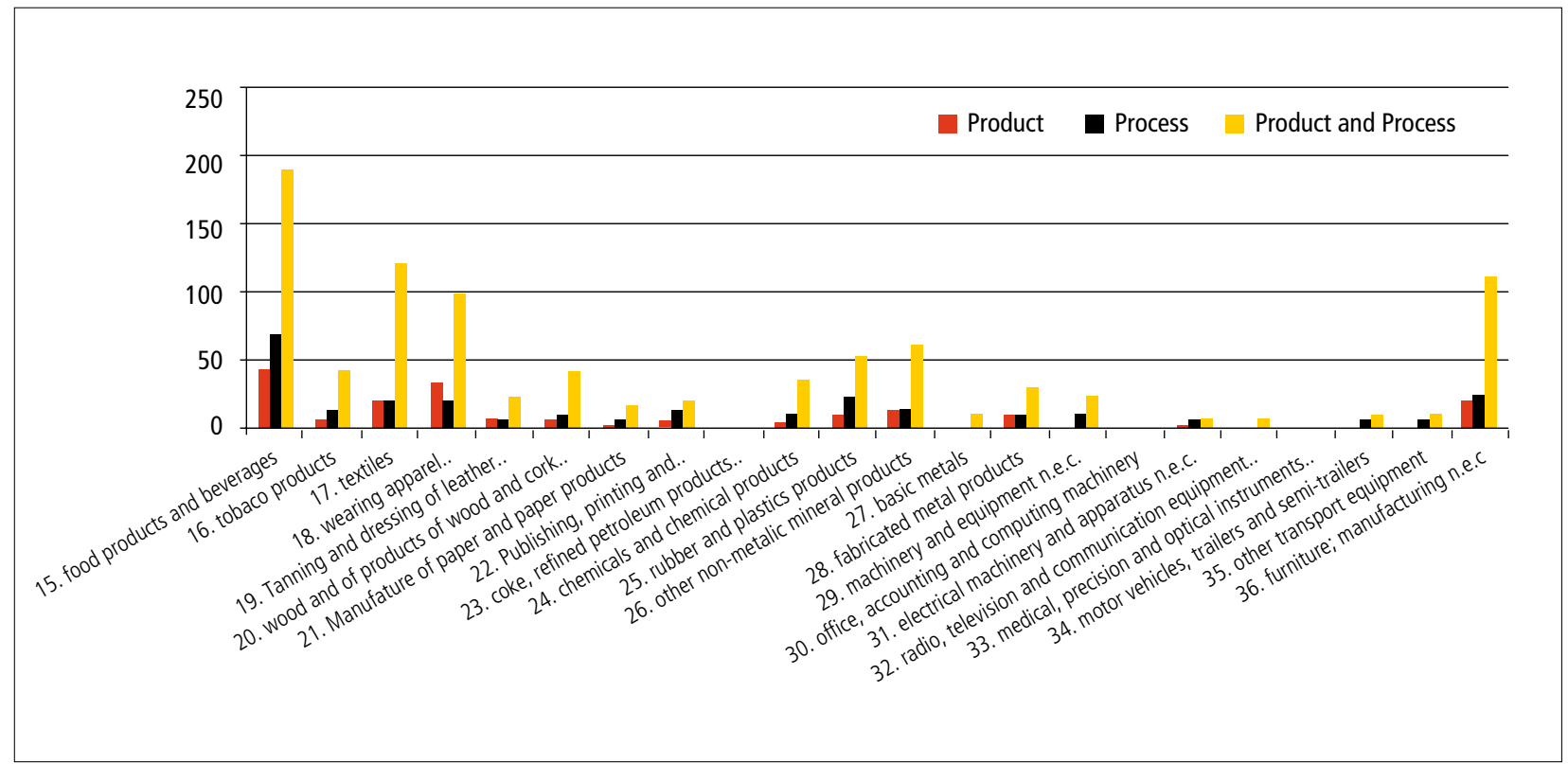

Fig. 3. Industial Innovation

Source: Innovation of Manufacture Industries's Survey, 2009 PAPPIPTEK-LIPI 


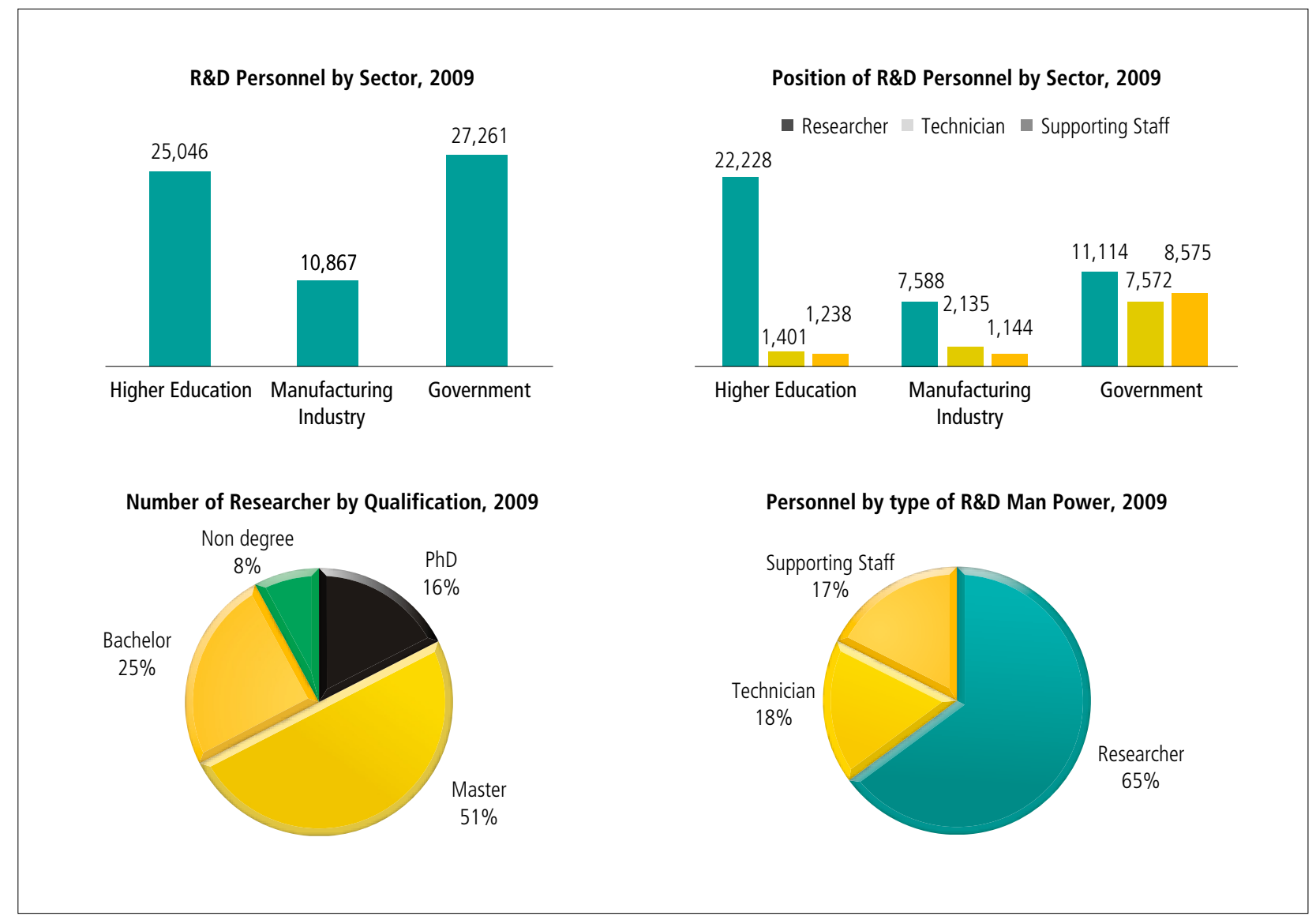

Fig. 4. R\&D Personnel

Source: Indonesian Institute of Sciences (LIPI) Center for Science and Technology Development Studies (PAPPIPTEK)

\section{THE 1-747 INITIATIVE, STP DEVELOPMENT AND THE SPECIAL ECONOMIC ZONE}

The ability of a nation to promote sustainable economic growth depends heavily on the ability of the nations to improve innovation. Innovation based on the capitalization of technology research products will make an immediate impact on improving sustainable productivity, which in turn can accelerate the economic growth of a nation. The ability to master science and technology is a basic capital to create innovations that will be useful to develop the economy in order to face global competition. The efforts to increase productivity towards the creation of competitive advantage can be achieved with the innovation based human resource capacity development. The legacy of natural resource-based economy, which is labor intensive, needs to be gradually improved towards skilled labor intensive and eventually to human capital intensive. The improvement of human capital mastering science and technology is highly needed when Indonesia enters into the innovation-driven economies stage. ${ }^{3}$

To achieve that goal, Indonesia's National Innovation Committee (KIN) formulate the concept "1-747 innovation initiative" to increasing productivities: $1 \%$ of GDP for R\&D, 7 steps of innovation system improvement, 4 models of economic growth acceleration, and 7 objectives of Indonesia's vision 2025. This innovation initiative as a key driver in the transformation to innovation-based economic (IBE) system

${ }^{3}$ Manual Book of Initiative 1-747, Indonesia's National Innovation Committee (KIN) Book 2012. 
PRESIDENT'S INITIATIVE : 1-747

1\% of GDP
per year
$\begin{aligned} & \text { To support innovation pro- } \\ & \text { gram through } 747 \text { scheme, } \\ & \text { R\&D fund which is around } \\ & 1 \% \text { of GDP until } 2014 \text { is } \\ & \text { needed. } \\ & \text { The increase in R \& D fund } \\ & \text { can be realized gradually } \\ & \text { based on government's } \\ & \text { capacity, and also SOE's and } \\ & \text { private participation }\end{aligned}$

INPUT

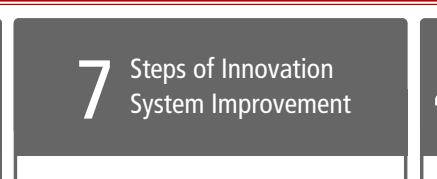

1. Introduce incentive and regulation system that support innovation and use of domestic products

2. Improve the quality and flexibility of human resource movement

3. Develop innovation centers to support small and medium industry 4. Develop regional innovation clusters

5. Enhance researcher's remuneration system

6. Develop R \& D Infrastructure

7. Develop research funding system and management that support innovation

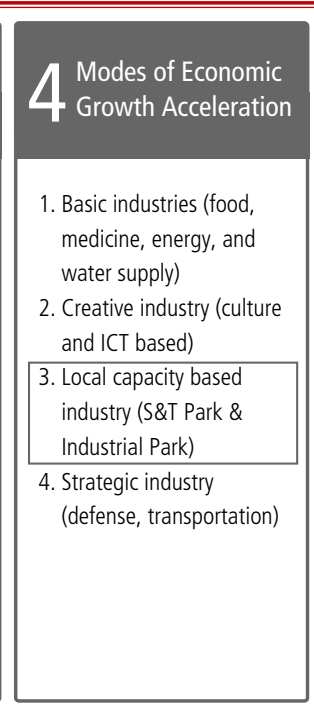

PROCESS

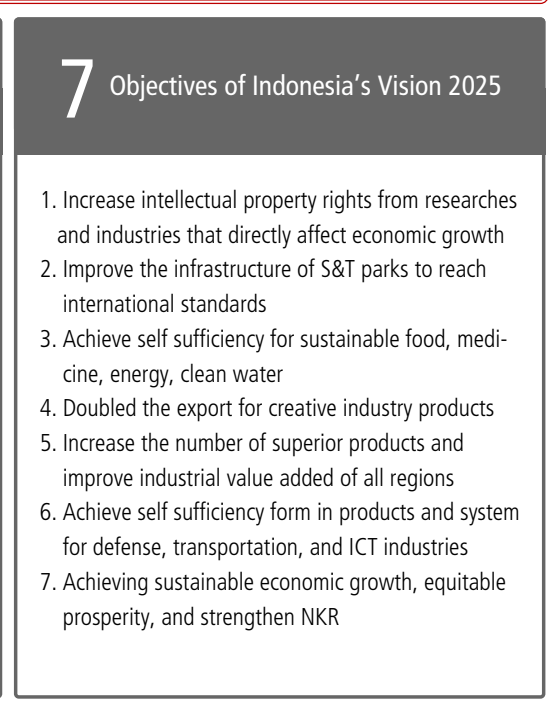

OUTPUT

Fig. 6. Innovation Source

Source: Master Plan of Acceleration and Expansion of Indonesia's Economic (MP3EI) 2011-2025, Presidential Regulation No. 32 of 2011

by strengthening the education system (human capital) and technological readiness.

The figure above shows that one of seven steps to improve innovation system is to develop regional innovation cluster, which is STP. STP can be called as regional innovation cluster because as its philosophy STP developed to accelerate and increase regional innovation so science and technology can contribute to regional economic development. Furthermore, in "1-747 innovation initiative" also stated that local capacity based industries which supported by STP and industrial park is a model to accelerate economic growth. In addition, Indonesia need to create STP not only to increase regional innovation and accelerate economic growth but also to increase regional and national competitiveness. As in fact and according to the data above, Indonesian is facing many problem on science and technology development such as low of competitiveness, innovation still limited mostly at food and beverage industry, only $27 \%$ industry has create research collaboration, research institute not a source of innovation, etc. To overcome that problem, Indonesia has initiated and created STP at many region.

The development of STP can be considered as a key suc- cess oriented with knowledge based economic (KBE) and innovation based on regional policy. STP is a RIS that can affect regional economic activity. Developing STP in different areas is a definite step to encourage science and technology to contribute for the economy in the regional economy.

STP is also a vehicle to explore potential resources by utilizing existing science and technology. In other words, STP has been implementing the concept of KBE or IBE and utilizing of existing resources using science and technology. There are four advantages of developing STP:

(a) Stimulating and manage the flow of knowledge and technology between universities and industry.

(b) Facilitating the communication between industry, universities, and industries.

(c) Providing environments that enhance a culture of innovation, creativity and quality.

(d) Facilitating the creation of new businesses via incubation and spin-off mechanisms, and accelerate the growth of small and medium size companies.

So that STP is one of the instruments to reinforce NIS and RIS. It is also to explore regional resource and improving the relationship between academia, business, and government 


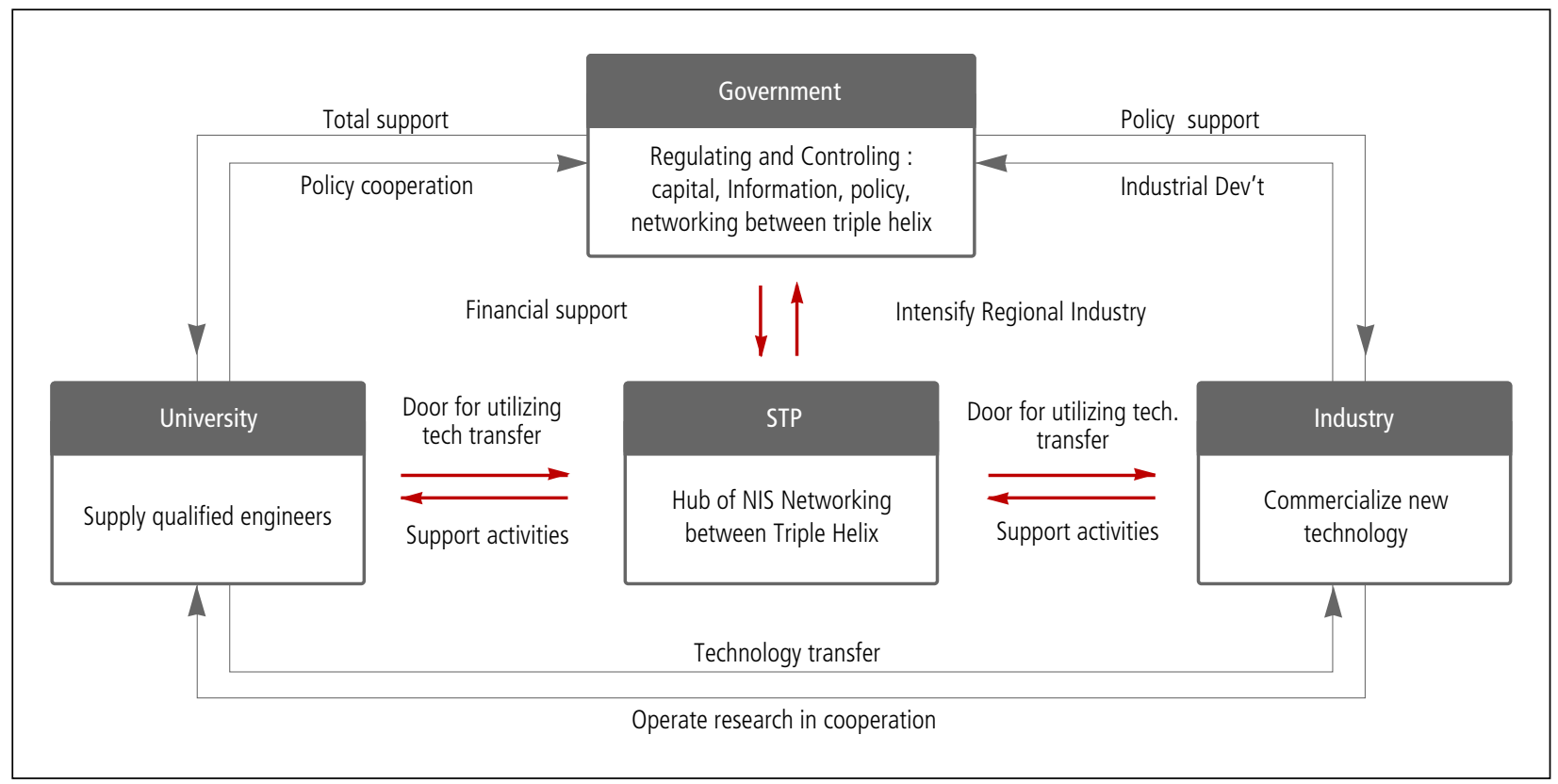

Fig. 7. Relationship between STP and NIS /RIS

Source: Action Plan ISTP 2010 arranged by UNESCO-WTA and Ministry of Research And Technology Republic Of Indonesia

(triple helix) as $<$ Fig. $7>$ below.

Developing STP in Indonesia will be adapted by concept of industrial clusters and special economic zone (SEZ). In this case, STP plays an important role in supporting the implementation of MP3EI. STP support increasing innovation based economic potential in six Indonesian regional economic corridors of MP3EI. STP is expected to grow into an SEZ or a significant part of the SEZs that cultivate innovation-based businesses and industries. In the other word, Indonesia is divided into economic corridors within the corridors there are SEZ and within a SEZ there are a number of clusters. A SEZ is a special region that has more free market economy tendencies. For example, some official state regulations on trade might not be fully implemented inside a SEZ. The development of SEZ regions is a key factor in the government's efforts to successfully implement the MP3EI and the success of SEZ is by developing STP as a tool to increase regional innovation.

\section{CONCEPT AND EARLY STAGES OF STPS DEVELOPMENT IN INDONESIA}

NSTP aims to contain a multi-industry cluster that will
Some areas in Indonesia have already and in the process of developing STP to support the local economy based on innovation. At this time (2013) there have been developed 4 STPs: Bandung Techno Park, Solo Techno Park, Cikarang Techno Park, and Puspiptek. Meanwhile, being developed Batam Technopark and Palembang Technopark. Some STP was initiated by the local government (Solo and Batam), University (Bandung and Solo), and Business Performer (Cikarang).

\subsection{Solo Techno Park}

Solo Techno Park (STP) is constructed to boost up regional innovation in improving the city's competitive edge. Solo Techno Park is a center for vocation and technological innovation in Surakarta, built form solid synergy and relationship of education, business, and government (the triple helix) and community. Solo Techno Park provides : (1) Education and Training for young job seekers, vocational school teachers, and industry employees; (2) Consulting and Training competency tests; (3) General Welding and Under water wet Welding Training; (4) Industrial Practice for Vocational High School Students Surakarta; and (5) Technology Business Incubator training program.

Cooperation between industry and STP related to the 
recruitment of graduate skilled labor is conducted well and the amount of demand from the industry cannot be fulfilled due to the limitationof the graduate skilled labor. There are also some industry as the service production consumer which put the work to STP, therefore it gives the authentic training for the participant to have real industry area learning as they learn to face the risk as the products used for the practice are the production component which known as production based education and training (PBET).

The development of Solo Techno Park as early science park in Indonesia related by collaboration between the triple helix. At Solo Techno Park there is university such as Meta ATMI, industry such as PT. Solo Manufaktur Kreasi, and Government such as regional government of Surakarta. Eventhough there is the triple helix, but its collaboration still weak.

\subsection{Bandung Techno Park}

Bandung Techno Park (BTP) serves as an intermediator and synergy builders among Academics, Business Sector/Industry, Government and Community, which is abbreviated as ABGC. As Business Incubator, main activities of BTP are growing the new start-up or tenant with some services as follows: (1) Business Mediation. BTP linking the new start-up/tenant with its own product to potential market; (2) Production Support. BTP is also support the startup/tenant with production facilities by cooperating with industrial party; (3) Innovation Center. BTP provide some facilities for communities to grow and discover new innovation in ICT field; and (4) Training and Consultancy. BTP provide training and consultancy service specifically in the field of ICT. This service is open for public. There are four main parties involves in BTP activities. These parties are Government, Industry, Universities, and BTP itself. BTP perform as intermediator and synergy builder among these parties to develop Indonesian ICT industry. The relation among these four parties with BTP in the center is illustrated by the following picture.

The $<$ Fig. $8>$ shows linkage between triple helix at Bandung Techno Park. There are university such as ITT Telkom, industry, and government. But, in fact the collaboration between the triple helix also still weak. Local government does not fully support the activity of Bandung Techno Park.

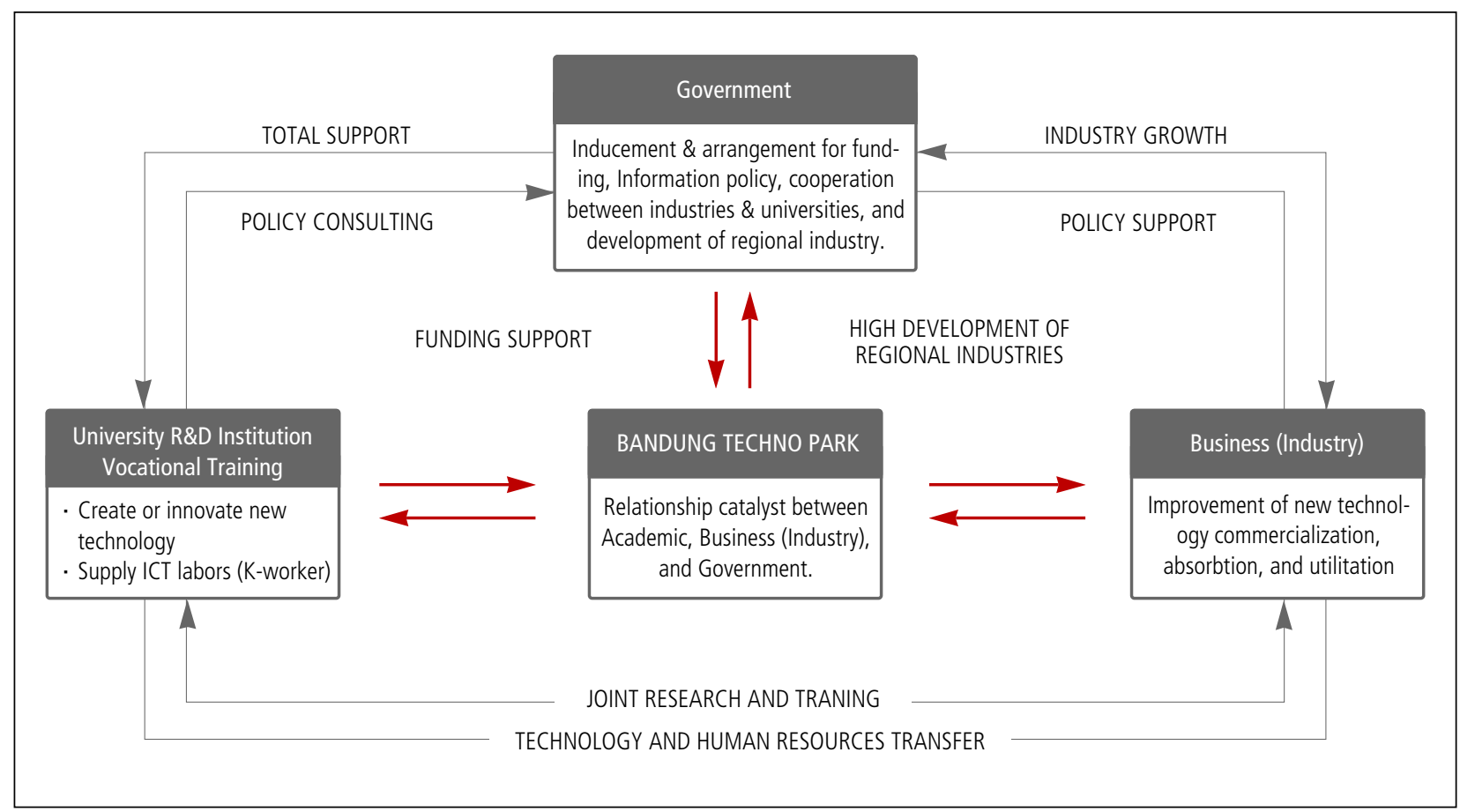

Fig. 8. Linkage between Triple Helix at Bandung Techno Park

Source: Presentation Bandung Techno Park's Delegation at UNESCO - WTA Training Workshop 2012 


\section{Best Practice of Science / Technology Parks}

\subsection{Batam Technopark}

The local government of Batam expected that Batam Techno Park will create an environment of innovation and Research and Bussines Development (R\&BD), creating a Start-Up SME as well as helping to improve human resources and strengthen the Innovation System in Batam and Indonesia. In the future, Batam Techno Park is expected to change the face of the industry in Batam from labor-based incentives to industries that have high added value by strengthening technological innovation system. Concept of Batam Techno Park as services centre for R\&BD, business incubation, education (Workshop, certification), Mediation and Business Support, Clustering Industries and production functions could be done through "One Stop Services" in a way of one-stop activities under one roof.

Batam Techno Park will cooperation with several ministries (industry, trade and related ministries), university, Batam State Polytechnic, Batam IT Center, industries and other stakeholders in Batam. Currently Batam Techno Park has cooperation with the Institute of Technology Bandung and Batam State Polytechnic of in the development of prototype electronic product produced by the "Micro Bandung Electronic Center" with product Wireless Broadband Access (WIMAX) which will be in production in Teaching Factory facility in Batam Techno Park. Batam Techno Park is a Tunneling Corridor between Sumatra and West Java Corridor which MP3EI program is on the development of the ICT sector, the Industrial Development and improvement of the quality of human resources.

\subsection{The Indonesian Research Centre For Science and Technlogy (Puspiptek)}

Puspiptek, located in Serpong $(30 \mathrm{~km}$ for Central of Jakarta), was one of a set of the Indonesian government prestigious projects started in 1976. It is complex of 460 ha which was planned as a national platform to host public research institutes, knowledge based enterprises and their support facilities. According to the original plan, Puspiptek was expected to be part of the Science Based Industrial Park which will be developed in Serpong. Unfortunately, more almost 35 year later, this plan is still not implemented.

Currently, the Puspiptek, which is coordinated by Ministry of Research and Technology, hosts 4 government research institutes (with more than 30 different laboratories) which are affiliated to the Indonesian Institute for Science (LIPI), the Agency for the Assessment and Application of
Technology (BPPT), the National Nuclear Energy Agency (BATAN) and the Environmental Impact Management Agency (PUSARPEDAL). The research centers conduct research and development, provide service for maintenance, repair and testing machinery equipment, and organize training. So far, there is no private company in that complex. As the matter of facts, Puspiptek is only an aggregate of public research institutes. Each research institute has its own facilities and operates independently without any coordination from the Puspiptek. This situation can be asserted that Puspiptek presently is just as research park only, because there are no collaboration between research institutes, industries or company, and government to develop science and technology. In the future, Puspiptek will be revitalized as a Indonesia Science and Technology Park (ISTP) that have linkage with industry.

As part of the revitalization and development program of Puspiptek, since 2008 Puspiptek has cooperation with UNESCO and WTA in these activities. ISTP has mission to establish as an international platform to promote science, technology and innovation by facilitating cooperation among research centers, universities, industry and government within the framework of the NIS.

ISTP will be a hub of NIS and RIS, who connecting government (central and regional government), universities, research center, and Industries or venture firms in the area. The implementation plan of the ISTP could be divided into three following steps. There are pre-incubation, incubation and post incubation. The three steps could be started at the same time. There is no need to wait until the tenants in incubator graduated to start the start the development of high technology industrial park. The process to incubate the starup company can be done at the sometime with champagne to attract the mature knowledge based company into the park.

Ministry of Research and Technology have some effort to encourage Puspiptek toward ISTP, such as improving intermediation and incubation function; conducting entrepreneurship training; cooperating with local government; increasing budgeting allocation to renew laboratories's apparatus in Puspiptek; growing up human resources, collaboration among stakeholders, government, and nongovernmental component, Establish standard laboratories at Puspiptek; and improving international cooperation. Besides that, Puspiptek also have some international cooperation to develop ISTP such as UNESCO, WTA, Gwangju Techno Park, 


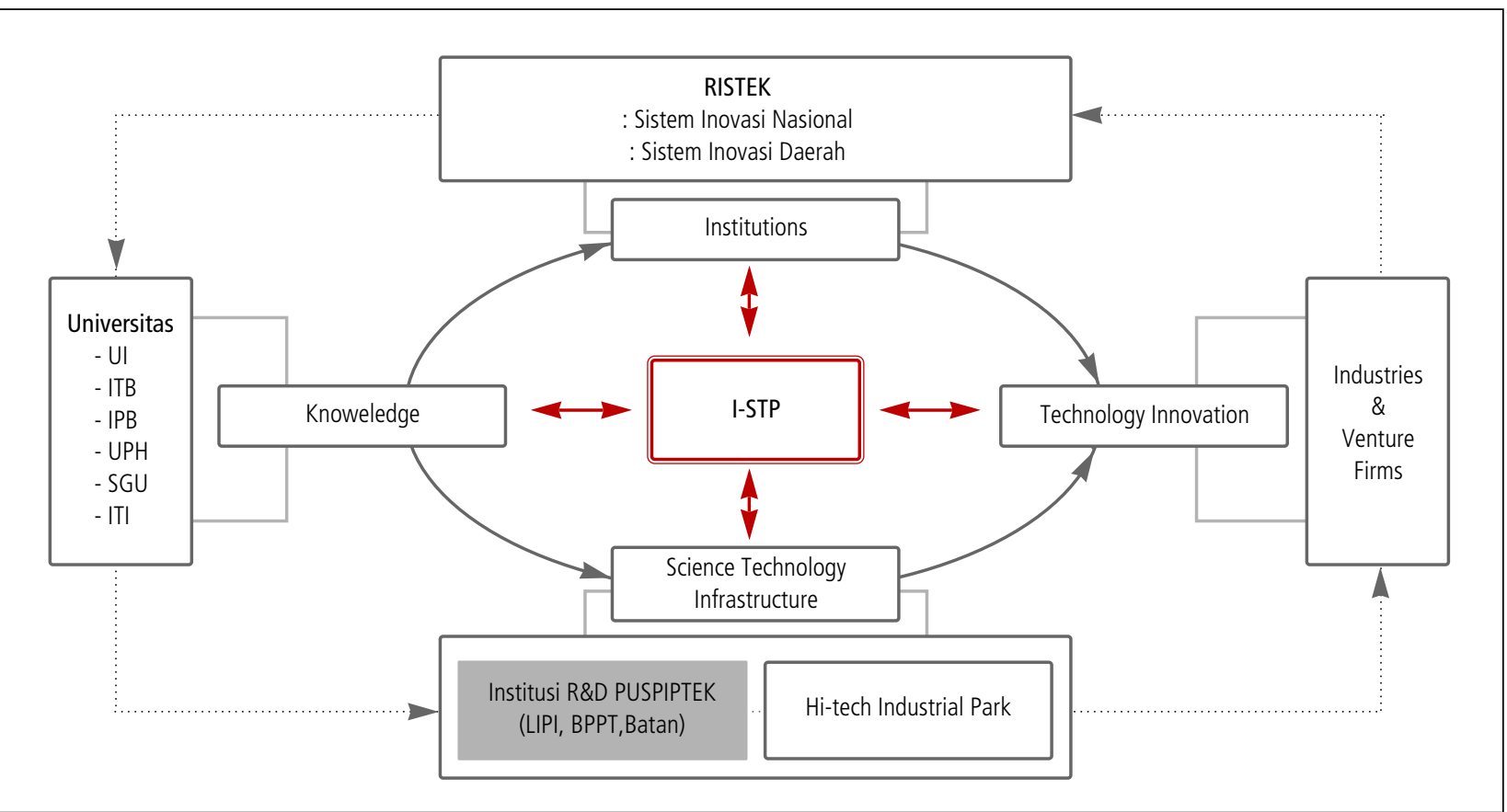

Fig. 9. ISTP as hub for RIS/NIS

Source: Action Plan ISTP 2010 arranged by UNESCO - WTA and Ministry of Research And Technology Republic Of Indonesia

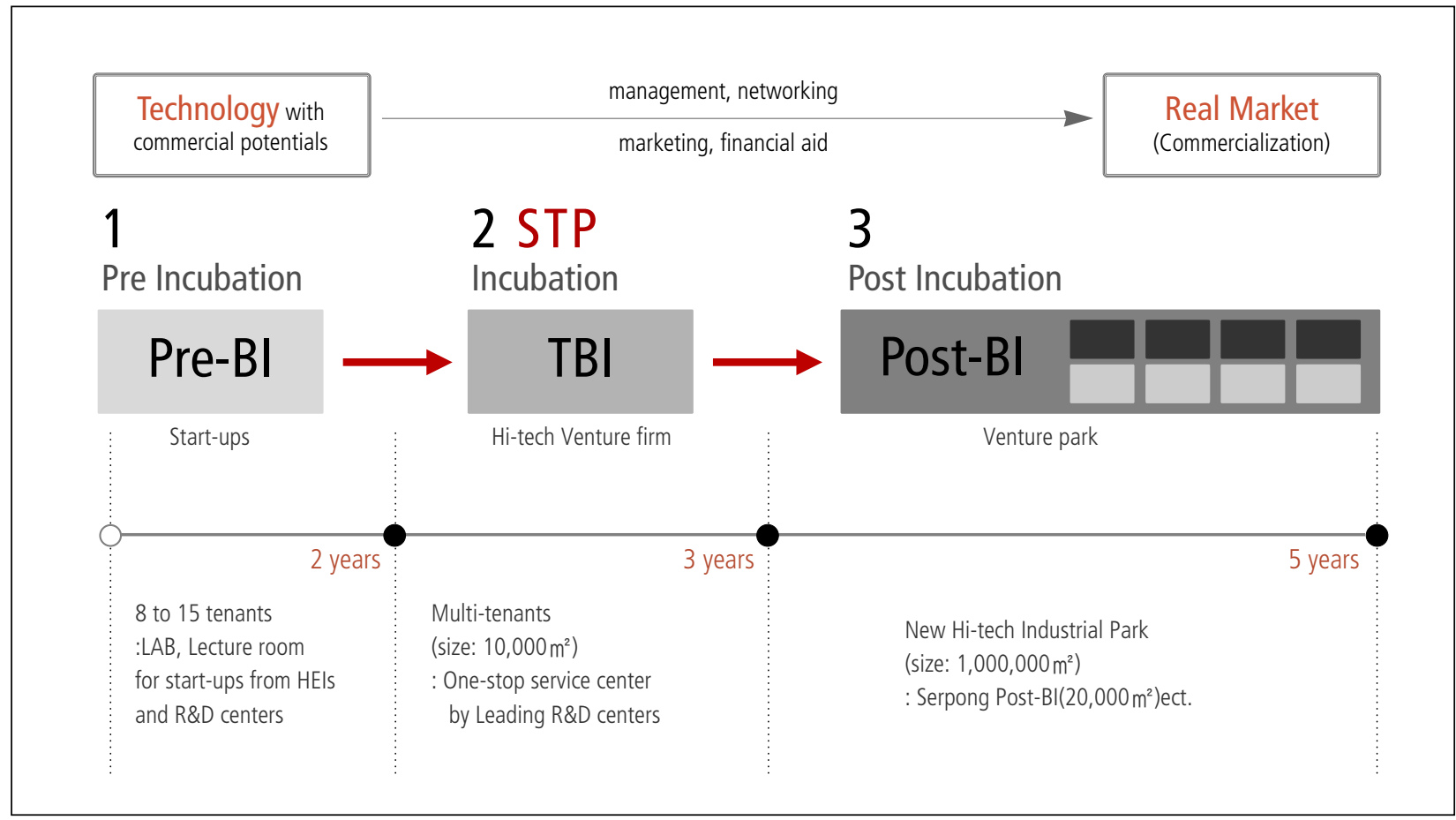

Fig. 10. Long-term Development Plan of ISTP

Source: Action Plan ISTP 2010 arranged by UNESCO-WTA and Ministry of Research And Technology Republic Of Indonesia 
Chungnam National University, and in progress with Chungnam and Chungbuk Techno Park.

From the $<$ Fig. $10>$ above, the implementation plan of the Indonesia Science \& Technology Park could be divided into three following steps: pre-incubation, incubation and post incubation. The three steps could be started at the same time. There is no need to wait until the tenants in incubator graduated to start the start the development of high technology industrial park. The process to incubate the star-up company can be done at the sometime with champagne to attract the mature knowledge based company into the park.

\section{CONCLUSION}

Indonesia facing many problem related to develop science and technology indeed such as there are no collaboration between triple helix, no innovation in industry, lack of research institutes role to make innovation in industry even if Indonesia have national research agenda (ARN), and so on. But, The Indonesian government is fully convinced that innovation is an important aspect in supporting the economy. Also, the government concerns that by developing innovation and science and technology especially at manufacturing sector can increase economic development.

To increase innovation, Indonesia through the "1-747 innovation initiative," set 4 vehicles accelerating economic growth, one of them carrying capacity based industrial growth area with supported by STP. In the concept of innovation based economic growth in six economic corridors, STP is expected to be an important element, especially in support SEZ. The concept of STP in SEZ area is a good way to make linkage between industry and center for research like STP in frame of NIS and RIS. STP as a center for research in SEZ also have a role to linkage and collaboration between the triple helix. Thus it also can increase national competitiveness. In addition, STP will encourage and foster an environment of technopreneurship in the community, which in turn create jobs for local people.

Currently, Indonesia have some STP in Bandung, Solo, Cikarang and Puspiptek in Serpong. The Indonesian government continues to encourage the development of STP in these areas, with the support of local governments, universities, and businesses as well as relevant stakeholders in the area. Especially Puspiptek need to revitalize from research center toward ISTP in order to make linkage and collaboration between triple helix. Meanwhile, Batam and Palembang are also starting the process of STP development in the region. Development stage of STP in Indonesia is still at an early stage, and not yet fully able to synergize the three main elements of triple helix.

Therefore, Ministry of Research and Technology has been coordinating and facilitating the triple helix to make collaboration. Also Ministry of Research and Technology develop policy in implementing ABG's cooperation and as leader in coordination among government agencies. Related by STP development, Ministry of Reseach and Technology will socialize the role of science and technology park to stakeholders, central and local government systematic support; creating good infrastructure; encouraging research collaboration; and incresing reseach and development fund and incentive.

\section{REFERENCES}

Oh, D.S (2010) Guideline \& Manual of Science Park Development : A Study on The Science Park Development Strategy Base on Daedeok Innopolis, Global Business Team, p. 7.

Indonesian Institute of Sciences(2012) (LIPI) - Center for Science and Technology Development Studies (PAPPIPTEK).

Indonesia, Law of The Republic Of Indonesia On National System Of The Research, Development And Application OF Science And Technology, Law Number 18 Of 2002.

Indonesia, Presidential Regulation Number 32 Year 2011.

Indonesia National Research Agenda 2010-2014.

Ministry of Research and Technology (2011) "Inovasi untuk Kesejabteraan Rakyat," Jakarta.

World Economic Forum (2011) Global Competitiveness Report 2012-2013. Available at http://www.weforum.org/gcr.

“Action Plan ISTP 2010" arranged by UNESCO-WTA and Ministry of Research And Technology Republic Of Indonesia. 